\title{
man \\ Diversity of Coral Reef Fishes in the Western Indian Ocean: Implications for Conservation
}

\author{
Melita Samoilys ${ }^{1,2, *(\mathbb{D})}$, Lorenzo Alvarez-Filip ${ }^{3}$ (D), Robert Myers ${ }^{4}$ and Pascale Chabanet ${ }^{5}$ (i) \\ 1 CORDIO East Africa, P.O. Box 10135, Mombasa 80101, Kenya \\ 2 Department of Zoology, University of Oxford, Oxford OX1 3PS, UK \\ 3 Biodiversity and Reef Conservation Laboratory, Unidad Académica de Sistemas Arrecifales, \\ Instituto de Ciencias del Mar y Limnología, Universidad Nacional Autónoma de México, \\ Puerto Morelos 4510, Mexico; lorenzoaf@gmail.com \\ 4 Seaclicks/Coral Graphics, 33411 Wellington, FL, USA; robmyers1423@gmail.com \\ 5 UMR ENTROPIE (IRD, UR, CNRS, IFREMER, UNC), CS 41096, 2 Rue Joseph Wetzell, \\ 97495 La Reunion, France; pascale.chabanet@ird.fr \\ * Correspondence: msamoilys@cordioea.net; Tel.: +254-721498713
}

Citation: Samoilys, M.; Alvarez-Filip, L.; Myers, R.; Chabanet, P. Diversity of Coral Reef Fishes in the Western Indian Ocean: Implications for Conservation. Diversity 2022, 14, 102. https://doi.org/10.3390/d14020102 Academic Editor: Simone Montano

Received: 13 December 2021

Accepted: 26 January 2022

Published: 31 January 2022

Publisher's Note: MDPI stays neutral with regard to jurisdictional claims in published maps and institutional affiliations.

Copyright: (C) 2022 by the authors. Licensee MDPI, Basel, Switzerland. This article is an open access article distributed under the terms and conditions of the Creative Commons Attribution (CC BY) license (https:// creativecommons.org/licenses/by/ $4.0 /$ )

\begin{abstract}
Communities of coral reef fishes are changing due to global warming and overfishing. To understand these changes and inform conservation, knowledge of species diversity and distributions is needed. The western Indian Ocean (WIO) contains the second highest coral reef biodiversity hotspot globally, yet a detailed analysis of the diversity of coral reef fishes is lacking. This study developed a timed visual census method and recorded 356 species from 19 families across four countries in the WIO to examine patterns in species diversity. Species richness and composition differed most between the island countries of Madagascar and Comoros and both these locations differed from locations in Tanzania and Mozambique which were similar. These three regional groupings helped define WIO ecoregions for conservation planning. The highest species richness was found in Tanzania and Mozambique, and the lowest and most different species composition was found in Comoros. Biogeography explains these differences with naturally lower species diversity expected from the small, oceanic, and isolated islands of Comoros. Present day ocean currents maintain these diversity patterns and help explain the species composition in northeast Madagascar. Species distributions were driven by 46 of the 356 species; these provide guidance on important species for ongoing monitoring. The results provide a benchmark for testing future changes in reef fish species richness.
\end{abstract}

Keywords: coral reef fishes; species diversity; Indian Ocean; conservation; climate change

\section{Introduction}

Species are the fundamental units of ecosystems and thus species inventories and their distributions provide a foundation for understanding coral reef communities and their conservation $[1,2]$. Communities of reef-associated fish species reflect their biogeography, and this includes evolutionary history, sea surface temperature, and larval recruitment patterns driven by ocean currents [1,3-5]. But these reef fish communities are changing due to global warming and overfishing, which are rapidly degrading coral reefs globally [6-8], driving declines in abundance and local extirpations of some species [9,10]. Understanding these changes and informing conservation knowledge about patterns in species diversity is needed.

Marine provinces, first defined over 150 years ago [11,12], along with barriers to species dispersal $[13,14]$, provide a framework for understanding present day biogeographic patterns. The western Indian Ocean (WIO), is considered a distinct province of the Indo-Pacific region [15,16] and comprises 10 countries, all with coral reefs $[17,18]$. This province contains the second highest biodiversity hotspot in the Indo-Pacific, second to 
the Coral Triangle in the western Pacific [19-21]. Ten biogeographic subregions within the WIO Province were defined using hermatypic corals [22], with the diversity hotspot centered in the northern Mozambique Channel on the coasts of northern Madagascar, the Comoros Archipelago, northern Mozambique, and southern Tanzania (Figure 1), an area considered likely to host the highest diversity and abundance of other marine fauna [23]. Veron and coauthors [24], based on zooxanthellate coral distributions, confirmed similar coral ecoregions in the WIO but delineated 12 subregions by separating Comoros from Mozambique and Madagascar. These ecoregions provide important conservation planning units [25].

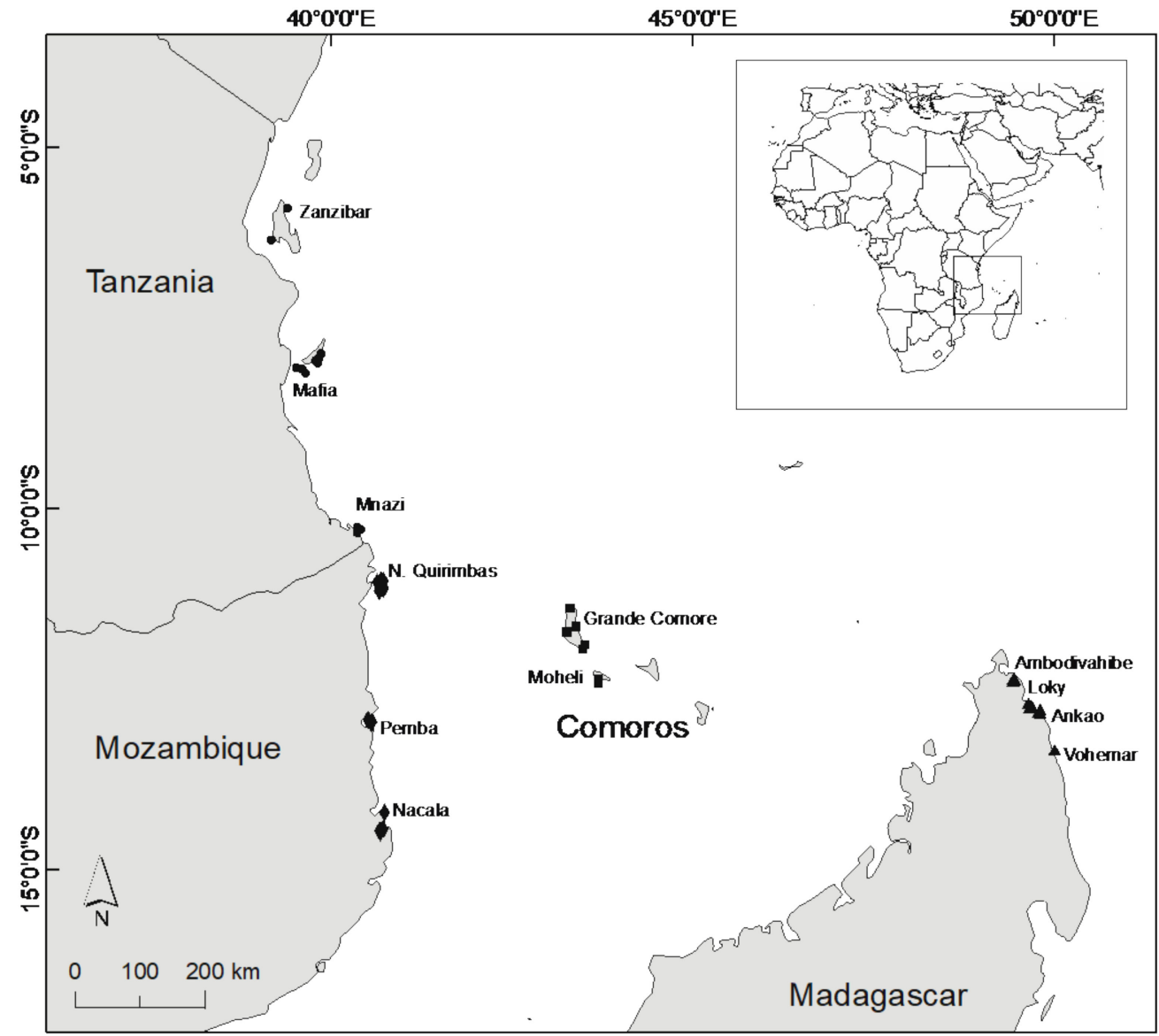

Figure 1. Map of study area showing countries and location of survey sites.

There are over 3000 tropical reef fish species found in the Indian Ocean, of which $74 \%$ range widely through the Indo-Pacific, thus giving $~ 850$ species restricted to the Indian Ocean [5]. The WIO Province supports just over 2400 fish species, representing a second peak in fish diversity in the Indo-Pacific after the Coral Triangle [19]. The highest fish species richness is found to the west on the eastern African continental coastline, with $\sim 600$ to 960 species. The highest level of endemism in the WIO is found to the east in the Mascarene Islands of Reunion and Mauritius. High endemism is typical of peripheral biogeographic regions $[15,26]$. Reef fish species' inventories in the WIO remain scattered and largely at a national level ranging from Madagascar [27,28], Comoros [29], Iles Eparses [30,31], to Reunion Island [32]. Therefore, data on species ranges are incomplete, though considerable early work established a sound base of identification sources [33,34]. However, a detailed regional analysis of the diversity of coral reef fishes in the WIO is lacking.

The present study developed a rapid underwater visual census method to compile reef fish species inventories across shallow reefs to examine biogeographic patterns in species assemblages across four countries. The study used the most diverse and/or most 
numeric families that occur on coral reefs in the Indo-Pacific [35], representing potentially around 460 coral reef species from the WIO $[3,27,34]$. Families selected represented those reported as indicators of biogeographical patterns and coral reef health, such as Chaetodontidae [36,37]; of fishery importance [38]; of both wide-ranging and restricted range species; and of Tetradontiformes, to expand the taxonomic diversity at the suborder level $[3,39,40]$. Two highly diverse families notably absent from this list are the Gobiidae and Blennidae, which are known to be excellent biodiversity indicators [41], however, they are too cryptic in their behavior and difficult to identify underwater while surveying a broad suite of species that range up to $\sim \mathrm{m}$ in length. The final 19 families rank highly in importance as indicators on coral reefs (Table 1 ) and comprises a potential species list that represents $\sim 50 \%$ of the putative total number of shallow coral reef species in the WIO [5]. This was therefore considered sufficiently broad and diverse to capture biogeographic patterns in the diversity of fishes within the region.

Table 1. Nineteen families surveyed for coral reef fish diversity analyses based on: (a) most speciose; (b) known indicators of aspects of fish communities; (c) fishery importance; (d) taxonomic diversity. Other rankings of coral reef fish families as indicators of diversity or importance on coral reefs are shown for comparison: Coral Reef Fish Diversity Index, CFDI A (Allen and Werner 2002); numerical abundance $C$ and B (Choat and Bellwood 1991); consensus list of 10 characteristic coral reef families, B (Bellwood 1996); global comparison of most speciose families ${ }^{B}$ and $W$ (Bellwood and Wainright 2002). These families are characteristic of coral reefs though not necessarily restricted to them and are among first 28 most speciose families of reef fish worldwide out of a possible 76 families (Bellwood and Wainright 2002).

\begin{tabular}{|c|c|c|c|c|c|c|}
\hline Order & Suborder & Families & CFDI $^{A}$ & Abundance ${ }^{\mathrm{C} \text { and } \mathrm{B}}$ & 10 Coral Reef ${ }^{\text {B }}$ & Most Speciose $B$ and $W$ \\
\hline \multirow{3}{*}{$\begin{array}{l}\text { Perciformes } \\
\text { (a) }\end{array}$} & Labroidei & Labridae (wrasse) & $x$ & $x$ & $x$ & 1 \\
\hline & Percoidei & Epinephelidae (groupers) & & & & 3 \\
\hline & Labroidei & Pomacentridae (damsel fishes) & $x$ & $x$ & $x$ & 2 \\
\hline \multirow{5}{*}{$\begin{array}{l}\text { Perciformes } \\
\text { (b) }\end{array}$} & Percoidei & Chaetodontidae (butterfly fishes) & $x$ & $x$ & $x$ & 6 \\
\hline & Labroidei & Scarinae (parrot fishes) ${ }^{1}$ & $x$ & & $X$ & 8 \\
\hline & Acanthuroidei & Acanthuridae (surgeon fishes) & $x$ & $X$ & $X$ & 7 \\
\hline & Percoidei & Lutjanidae (snappers) & & & & 10 \\
\hline & Percoidei & Pomacanthidae (angel fishes) & $x$ & & & 11 \\
\hline \multirow{6}{*}{$\begin{array}{l}\text { Perciformes } \\
\text { (c) }\end{array}$} & Percoidei & Lethrinidae (emperors) & & & & 13 \\
\hline & Percoidei & Haemulidae (grunts) & & & & 23 \\
\hline & Percoidei & Mullidae (goat fishes) & & & $x$ & 19 \\
\hline & Acanthuroidei & Siganidae (rabbit fishes) & & & & 21 \\
\hline & Percoidei & Nemipteridae (bream) & & & & 24 \\
\hline & Percoidei & Carangidae (trevally) & & & $x$ & $\mathrm{~N} / \mathrm{A}$ \\
\hline Perciformes (d) & Percoidei & Caesionidae (fusiliers) & & & & 28 \\
\hline Tetraodontiformes & Tetraodontiformes & Balistidae (trigger fishes) & & & & 16 \\
\hline Tetraodontiformes & Tetraodontiformes & Monacanthidae (file fishes) & & & & 14 \\
\hline Tetraodontiformes & Tetraodontiformes & Ostraciidae (box fishes) & & & & 25 \\
\hline Tetraodontiformes & Tetraodontiformes & Tetraodontidae (puffer fishes) & & & & 18 \\
\hline
\end{tabular}

${ }^{1}$ Scarinae are a subfamily within the Labridae (Bellwood et al. 2019) but for functional purposes are treated separately.

The current study aimed to examine patterns in species richness of reef fishes to contribute to our understanding of the biogeography of the less studied WIO province. It also aimed to assess how reef fish diversity patterns conform to known biodiversity hotspots and to delineate ecoregions in the WIO for coral reef conservation planning and threat assessments.

\section{Materials and Methods}

\subsection{Study Sites}

Coral reef fish species were recorded in 2009-2011 at 76 dive stations aligned to 45 sites which ranged from 1-33 $\mathrm{m}$ in depth (in the supplementary Table S1), spread across locations in four countries in the WIO: Madagascar, Comoros, Mozambique, and Tanzania (Figure 1) spanning latitude $-5.84^{\circ}$ (Zanzibar) to $-14.47^{\circ}$ (Nacala) and longitude 39.17 (Chumbe) 
to 50.01 (Vohemar). Sites surveyed in Comoros were in Ngazidja (Grand Comore) and Mwali (Moheli), two of the three islands in the Union of Comoros, which are referred to hereafter as Comoros. The fourth southeastern island in the Comoros Archipelago, Mayotte, an overseas department of France, is a larger island with considerably more reef habitat, but was not surveyed here. Each country's dataset is a sample and cannot claim to be representative of the country as a whole. Sites were selected haphazardly and ranged from shallow, protected fringing reefs to deep, exposed forereefs (Table S1). Each location encompassed sites across a large depth range and were therefore broadly comparable, though this negated any analysis for habitat effects (Table S1). Forereefs and deep and shallow terraces were prioritized as these reef types tend to have higher coral cover and rugosity, and hence, higher fish species diversity.

\subsection{Survey Method}

Coral reef fish diversity was measured by recording presence/absence of species on a SCUBA based underwater visual census (UVC) survey, which involved a timed swim by one observer throughout (MS), recording all species within visibility (mean $14.1 \mathrm{~m}$ ), supplemented with a few snorkel dives in shallow waters. The method was designed to provide sufficient breadth of species sampling, while remaining practically feasible for relatively rapid dive surveys across a large number of locations. The 19 families were selected based on those that are most speciose, are amenable to UVC (diurnal and not cryptic), have fishery importance, and included four Tetraodontiform families to extend the taxonomic diversity of the dataset (Table 1).

A complete species inventory of 19 families (Table 1) was recorded at each dive. Dive time and species richness were significantly correlated $\left(\mathrm{R}^{2}=0.19\right.$, slope $=0.27 \mathrm{x}+91$, $p<0.01)$ though taxonomic diversity was not $\left(\mathrm{R}^{2}<0.01\right.$, slope $\left.=-0.001 \mathrm{x}+63, p<0.86\right)$. The species richness curve showed a species plateau at $\geq 75 \mathrm{~min}$ dive duration. Consequently, data from the two replicate dive stations at each site were combined to ensure that each reef site was represented by 75-85 $\mathrm{min}$ of underwater observations. This conforms to recommended dive times of 60-90 min [27].

Species identifications were checked using photographs, taxonomic references, and photographic guides (see Table S2 for species list and references). Species names were verified from the online Catalog of Fishes [42].

\subsection{Data Analyses}

To assess overall patterns of species diversity, the species presence/absence data per reef site was used to calculate the total number of species and the average taxonomic distinctness (D+). The average taxonomic distinctness is a measurement of the average taxonomic path length between two randomly chosen species in the assemblage [43] and was increasingly applied because it is considered a good proxy of biodiversity and it is relatively independent of sampling effort [44]. Species richness and taxonomic distinctness were tested for differences between areas within countries and dive time. Species accumulation curves derived from the Michaelis-Menten index using 9999 permutations [43] were utilized to predict maximum species richness for each country. The Michaelis-Menten equation was chosen because it is independent of the rarity of a species, being based solely on presence. Furthermore, on empirical considerations it was also found to be the least biased by the number of samples and the most stable statistic to use for estimated maximum species richness on previous biogeographic studies in the Indian Ocean [22]. Differences between the predicted maximum species richness from the Michaelis-Menten equation and actual number of species observed in each country were compared using Chi-Square.

To detect similarity patterns in the species assemblages on reefs across the region the Bray-Curtis similarity index was calculated among pairs of sites, and the similarity coefficients used to run two ordination techniques to detect similarity patterns between sites [43]: a cluster analysis and a nonmetric multidimensional scaling (MDS). Both methods were applied as they offer complementary information. The significance of the differences 
between the geographical areas revealed in the cluster dendrogram and MDS plots was tested with an analysis of similarity (ANOSIM) based on randomization of the similarity matrix [43]. To investigate the main species that account for the observed patterns in species richness across the region, a similarity of percentage analysis (SIMPER) was used to detect the representative species of each geographical zone. Since the ANOSIM results showed significant country differences between Comoros and Madagascar, between these island countries and the mainland countries of Tanzania and Mozambique, and a marginal difference between the two mainland countries, the latter were combined as one, "mainland", for the SIMPER analysis.

\section{Results}

A total of 356 species from the 19 families (Table S2) were recorded from 45 sites across the four countries. Of these, 15 could not be identified to species but were either recorded to genus (10) or to a species it closely resembled from the Pacific Ocean (5). In all cases these uncertain species could be reidentified on subsequent surveys at different sites by the same observer (MS), and therefore, all were used in the analyses of species diversity.

Overall, the predicted number of species did not differ statistically from the observed number (Figure 2; Chi-square $=0.602 ; \mathrm{df}=3 ; p=0.89$ ). However, on a country-by-country basis, there was a marginally significant difference for Comoros (Chi-square $=3.9 ; \mathrm{df}=1$; $p=0.049$ ). This suggests that surveys from all locations in all four countries were adequate in providing representative values of total species richness, but there was some indication that an increase in the number of surveys in Comoros would improve the data. The results show, based on the 19 families, a predicted mean total number of species of 321 for Mozambique and 319 species for Tanzania, both higher than Comoros (267) and Madagascar (294) (Figure 2). Note that these numbers refer to locations surveyed in each country, and not the country as a whole (see Methods). Mean species diversity per site was highest in Mozambique followed closely by Tanzania, and lowest from sites in Comoros (Figure 3a). In contrast, taxonomic distinctness was highest in Comoros (Figure 3b). However, variability within countries was very high, for example, the highest species richness was recorded at Vamizi lagoon (152) and the lowest at Neptunes (82), both in northern Quirimbas, Mozambique (Supplementary Material Figure S1).

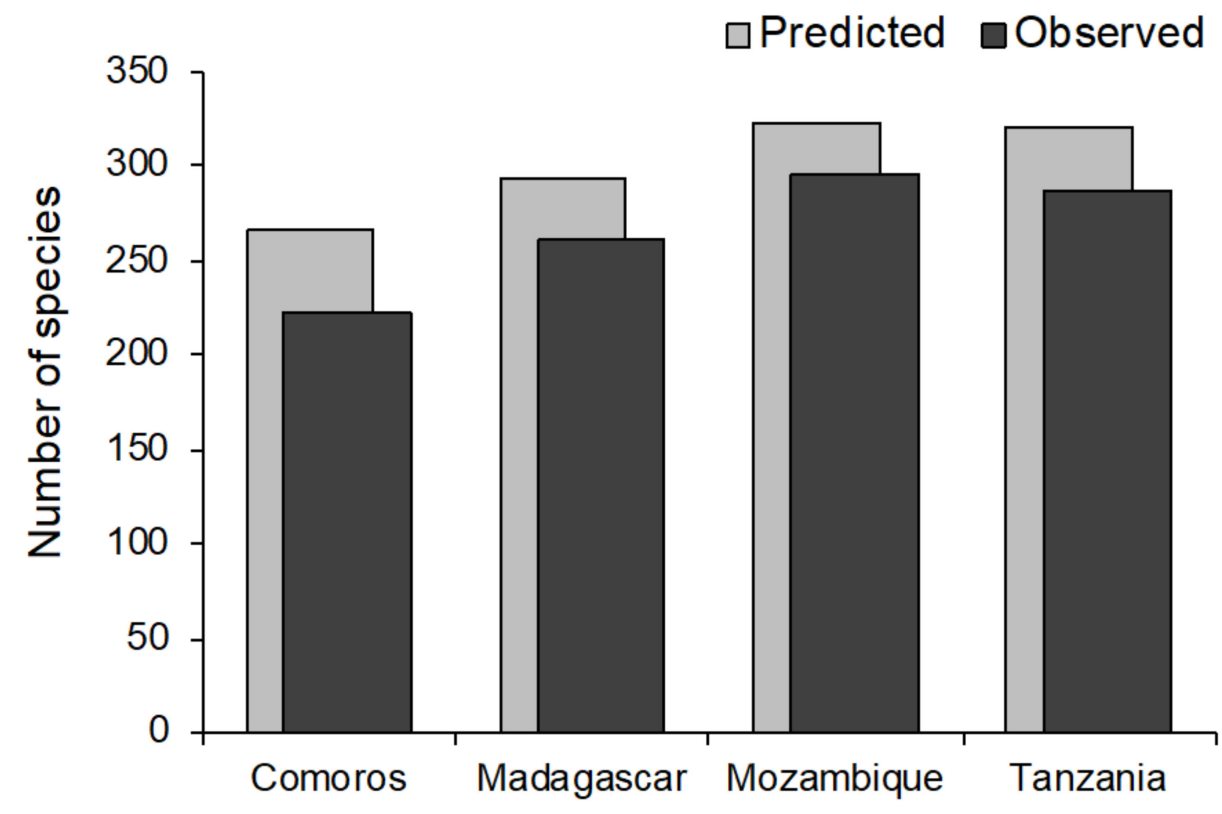

Figure 2. Total number of species observed (black) and predicted maximum species richness (grey) per country based on Michaelis-Menton permutations. Observed and predicted number did not differ significantly (Chi-square $=0.602 ; p=0.89$ ). Number of sites: Comoros: 7; Madagascar: 10; Mozambique: 16; Tanzania:12; 76 dives in total, as detailed in Table S1. 
a)

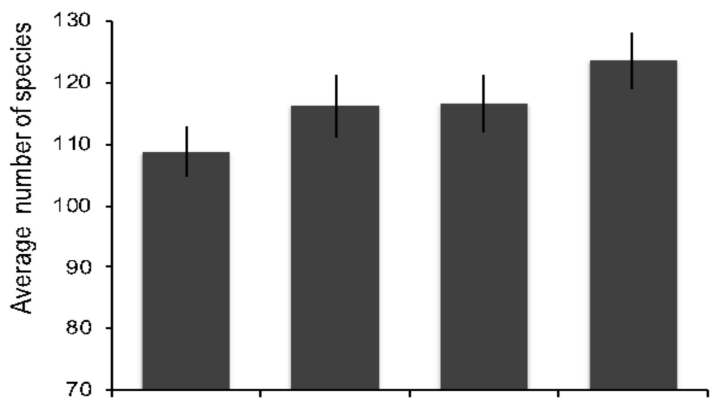

b)

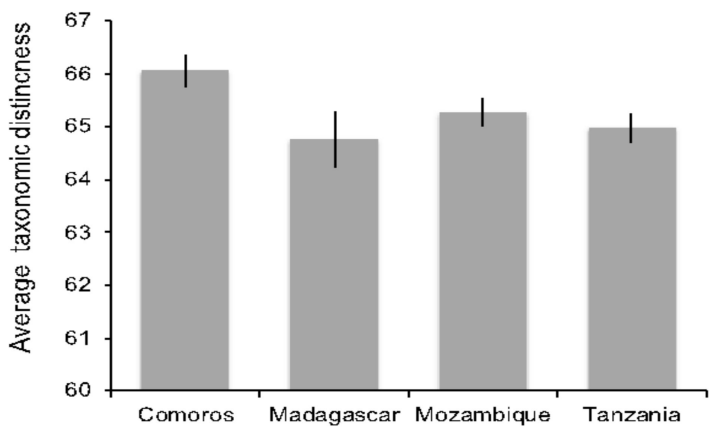

Figure 3. Mean fish species diversity: (a) mean total number of species observed per site (>75 min) in each country; (b) mean fish species diversity based on taxonomic distinctness (D+). Error bars are standard errors of mean. Sample sizes as in Figure 2.

Similarity in species' presence/absence between sites revealed four groupings at $54 \%$ similarity with all the Madagascar sites separate; the Comoros sites clustered separately; most of the sites from the African mainland, Tanzania, and Mozambique, clustered together in a complex set of smaller groups; and three extreme outliers of two sites from Mozambique and one from Tanzania (Figure 4). The same four groupings were confirmed in an MDS ordination though the stress level of 0.2 suggests country differences were not significant (Figure S2). The overall differences in species presence between the four countries were statistically different, with differences between sites in the two island countries, and between sites in island countries and mainland countries all highly significant, whereas differences between Tanzania and Mozambique were only marginally significant (Table 2).

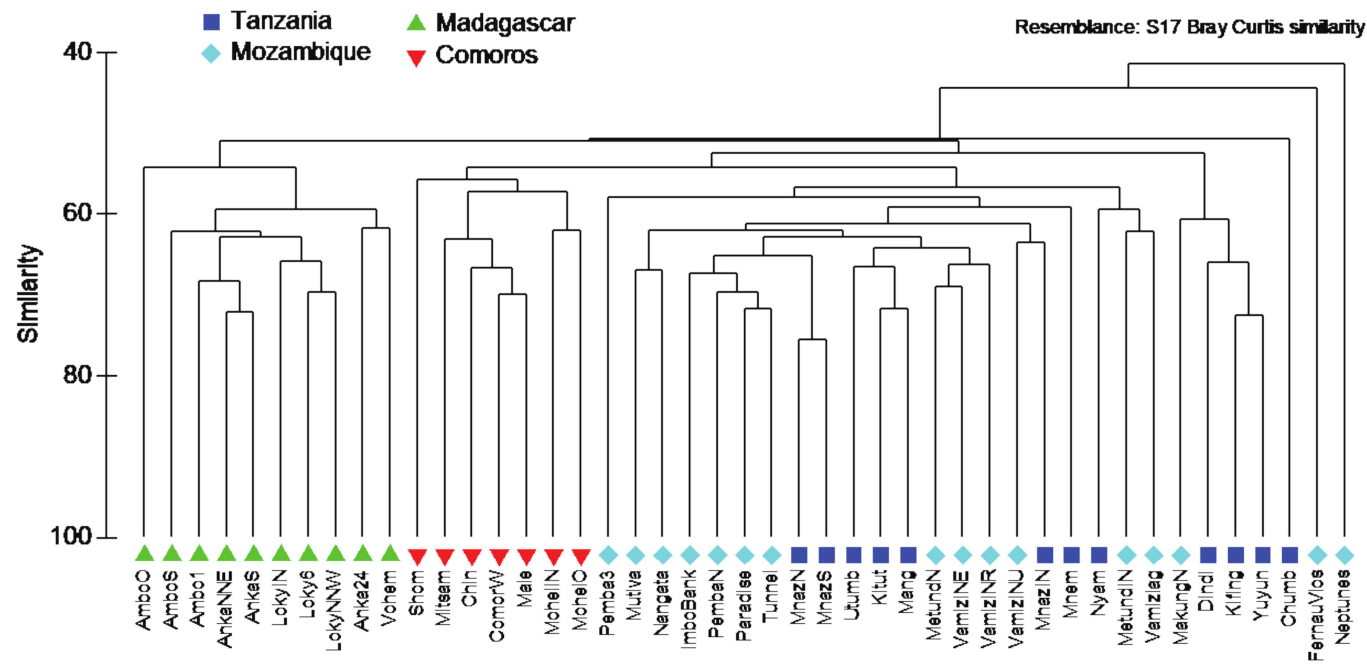

Figure 4. Bray Curtis cluster analysis showing similarity in species presence/absence between pairs of sites in western Indian Ocean (WIO). 
Table 2. Results of ANOSIM based on 999 permutations for differences in species richness between (a) countries and (b) between areas within mainland countries, Tanzania, and Mozambique (based on 999 permutations). Areas within mainland countries that differed significantly are bolded. Pemba is in Cabo Delgado, Mozambique.

\begin{tabular}{|c|c|c|}
\hline \multicolumn{3}{|c|}{$\begin{array}{l}\text { (a) Between Countries } \\
\text { Global } \mathrm{R}=0.405, p=0.001\end{array}$} \\
\hline Pairwise Tests-Groups & R Statistic & $p$ \\
\hline Madagascar, Comoros & 0.864 & 0.001 \\
\hline Madagascar, Tanzania & 0.592 & 0.001 \\
\hline Madagascar, Mozambique & 0.483 & 0.001 \\
\hline Comoros, Tanzania & 0.397 & 0.001 \\
\hline Comoros, Mozambique & 0.354 & 0.007 \\
\hline Tanzania, Mozambique & 0.103 & 0.048 \\
\hline \multicolumn{3}{|c|}{$\begin{array}{l}\text { (b) Between Areas within Mainland Countries } \\
\text { Global } \mathrm{R}=0.21 ; p=0.011\end{array}$} \\
\hline Pairwise Tests-Groups & R Statistic & $p$ \\
\hline Chumbe, Mafia & 0.617 & 0.056 \\
\hline Chumbe, Nacala & 0.321 & 0.200 \\
\hline Chumbe, Pemba & 0.857 & 0.067 \\
\hline Chumbe, Vamizi & 0.3 & 0.156 \\
\hline Chumbe, Mnazi & 0.583 & 0.100 \\
\hline Mafia, Nacala & 0.418 & 0.012 \\
\hline Mafia, Pemba & 0.489 & 0.009 \\
\hline Mafia, Vamizi & 0.131 & 0.061 \\
\hline Mafia, Mnazi & 0.173 & 0.225 \\
\hline Nacala, Pemba & -0.01 & 0.571 \\
\hline Nacala, Vamizi & 0.21 & 0.113 \\
\hline Nacala, Mnazi & 0.148 & 0.229 \\
\hline Pemba, Vamizi & 0.104 & 0.240 \\
\hline Pemba, Mnazi & 0.5 & 0.029 \\
\hline Vamizi, Mnazi & -0.113 & 0.636 \\
\hline
\end{tabular}

Fish species assemblages within the sites of the mainland countries, which ranged from $-5^{\circ}$ (Zanzibar-Mnemba) to $-14^{\circ}$ (Nacala sites with Fernau Vloso the southernmost), were different but similarity levels were relatively high, and there was no clear latitudinal or geographic pattern, though two outlier sites in Mozambique were apparent (Figures 4 and 5). None of these areas were statistically different from each other in terms of species presence except between two areas in Mozambique (Pemba, Nacala) and two areas in Tanzania (Mafia, Mnazi) (Table 2b). Though not statistically dissimilar (Figure 5), local scale differences in species richness suggested the following groupings (see Table S1 for reef types): (i) exposed forereefs at Mafia Island (Dindini, Yuyuni and Kifinge), similar to Makunga North, which had an exposed reef terrace, and a steeply sloping forereef in northern Mozambique; (ii) inner seas protected forereefs and lagoonal sites at Vamizi and Metundo islands in Mozambique; (iii) the largest group of similar reef sites ranging across the entire east African mainland with well-developed forereefs at ocean-exposed sites; (iv) outliers seen in Zanzibar: Chumbe, which is a narrow and relatively shallow (3-13 m) protected forereef with much sand and low rugosity; Mnemba, which is a relatively deep (to $18 \mathrm{~m}$ ) exposed forereef; and Nyamlile, a large patch reef off Mafia island. The significantly 
dissimilar extreme outliers in the whole plot (Figure 5) were two sites in Mozambique: Fernau Vlos in Nacala, a diffuse fringing forereef within the port channel with a few scattered corals on a sandy slope with some seagrass and little hard substrate, and Neptunes, which is an offshore deep terrace between Metundo and Vamizi islands with 90-degree walls dropping to around $500 \mathrm{~m}$. The walls are broken in places with canyons, and the upper terrace ranges from $\sim 7-12 \mathrm{~m}$ in depth.

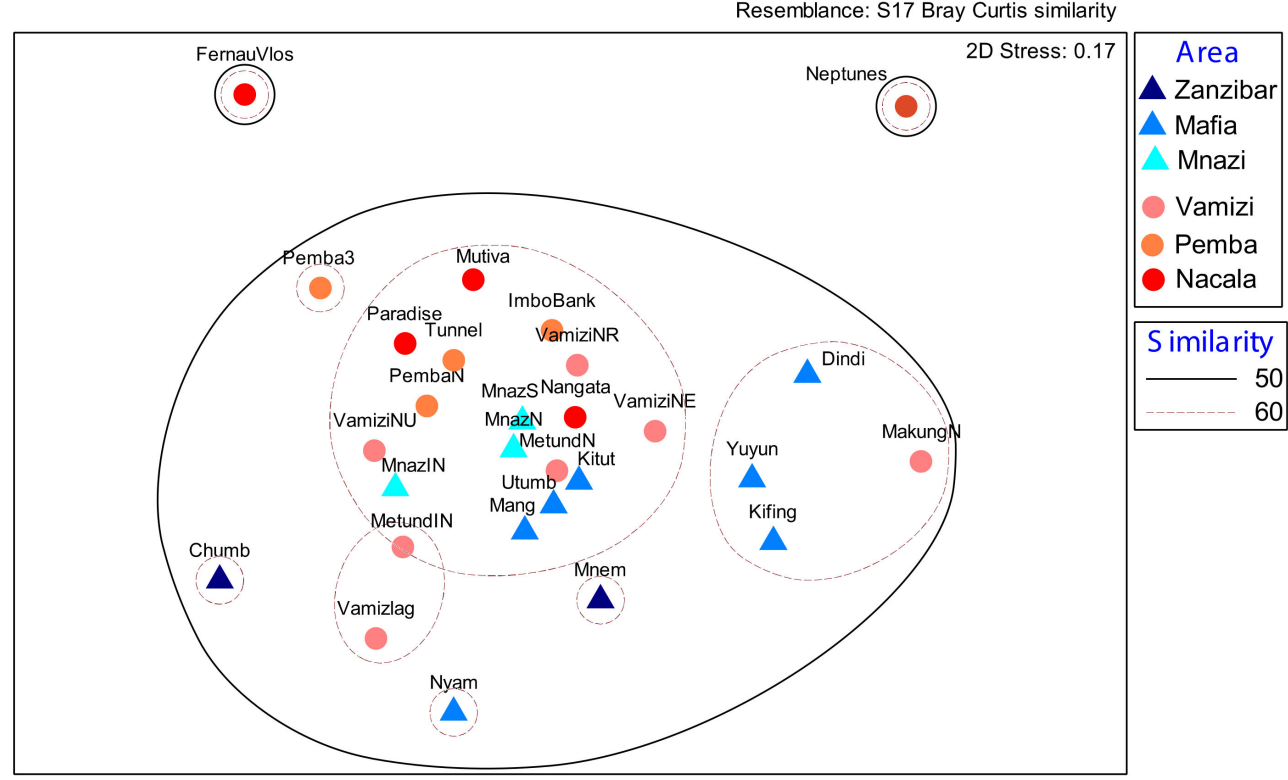

Figure 5. Multidimensional scaling (MDS) plot of mainland sites only, color coded with blues for northern sites (Tanzania) and reds for southern sites (Mozambique). Plot shows all sites are similar at $50 \%$, but within this large group three groups were apparent, though with similarity at $60 \%$ these groups were not strongly dissimilar.

Fish species composition and homogeneity were most dissimilar between sites in NE Madagascar and Comoros: of the first 14 high ranking species that contributed to the dissimilarity between all three geographical zone comparisons, 11 contributed most to the differences between Madagascar and Comoros, while the other three high ranking species, Pygoplites diacanthus, Heniochus acuminatus, and Cephalopholis argus, were significant in the other geographic zone comparisons (Table 3). Thus, the SIMPER results of species' average dissimilarity values are ranked according to the top 30 species that most explain the differences between Madagascar and Comoros (Table 3). These cumulatively explain 19.74\% of the dissimilarity in the species assemblages between these two geographic zones, and these species contributed between 56\% (Cheilinus trilobatus) to 85\% (Plectropomus punctatus) of the dissimilarity in this pairwise comparison (Table S3). The 10 most significant species in each of the three comparisons when combined gives 22 species in total. The average abundance shows that the species that ranked mostly highly had either, very high (0.9-1) relative abundance at sites (they were at most or all sites), or low or zero abundance (they were rare or absent at all sites) (Table 3).

The Madagascar - mainland pairwise comparison yielded many of the same species in explaining differences between assemblages as those seen in the Comoros-Madagascar comparison, but with three notable additions: Chaetodon falcula, Cephalopholis argus, and Amphiprion allardi (the latter two also significant in the Comoros-mainland comparison), as well as an additional eight species specific to Madagascar-mainland (Acanthurus xanthopterus to Calotomus carolinus, Table 3). In contrast, the Comoros-mainland comparison yielded several different species that did not rank highly in the other two SIMPER comparisons, notably Heniochus acuminatus, Aprion viriscens and Ostracion meleagris. Complete sets of all three pair-wise SIMPER geographic zone comparisons are provided in Table S3. 
Table 3. SIMPER results for most significant 47 species, showing first 30 species (Plectropomus punctatus to Cheilinus trilobatus) that explain $19.74 \%$ of dissimilarity in species present at sites according to Madagascar-Comoros dissimilarity cumulative ranking (grey columns), and 17 additional species representing those within top 20 species in other comparisons (12-14\% of cumulative mean dissimilarity/SD): (i) Madagascar-mainland comparison, and (ii) Comoros-mainland comparison Rank AvDiss = Dissimilarity/SD averaged across all three group comparisons is presented as a metric for ranking species that contributed most to differences across all three pair-wise comparisons. Twenty-two species in bold represent top 10 most significant species in all three pair-wise comparisons. Ranges (Catalog of Fishes 2021): IP = Indo-Pacific (includes west coast of Americas); IWP = Indo-West Pacific; IO = Indian Ocean; WIO = western Indian Ocean (Somalia to Mauritius); RS = Red Sea; EA = East Africa (Kenya, Tanzania, Mozambique, Comoros, Madagascar); Mas= Mascarene islands (Reunion, Mauritius, Rodrigues).

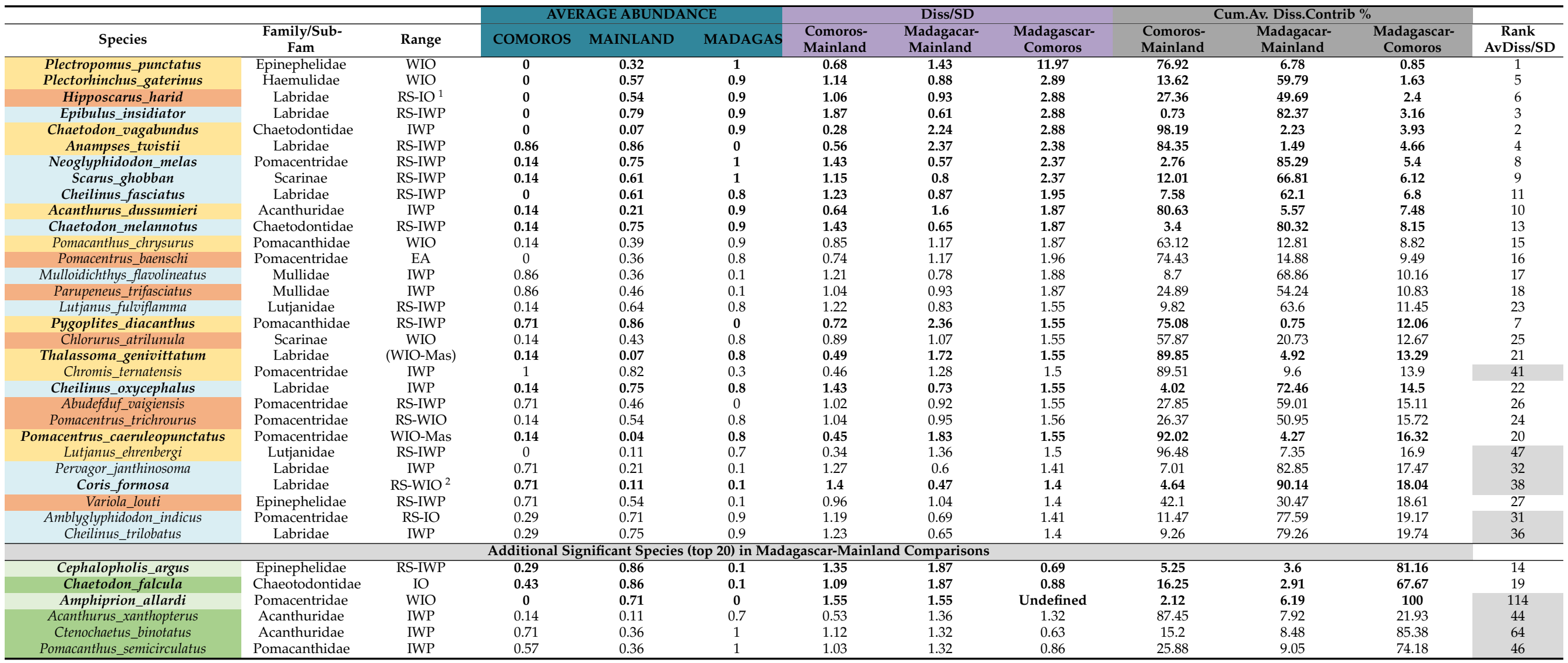


Table 3. Cont.

\begin{tabular}{|c|c|c|c|c|c|c|c|c|c|c|c|c|}
\hline \multirow[b]{2}{*}{ Species } & \multirow[b]{2}{*}{$\begin{array}{c}\text { Family/Sub- } \\
\text { Fam }\end{array}$} & \multirow[b]{2}{*}{ Range } & \multicolumn{3}{|c|}{ AVERAGE ABUNDANCE } & \multicolumn{3}{|c|}{ Diss/SD } & \multicolumn{3}{|c|}{ Cum.Av. Diss.Contrib \% } & \multirow[b]{2}{*}{$\begin{array}{c}\text { Rank } \\
\text { AvDiss/SD }\end{array}$} \\
\hline & & & cOMOROS & MAINLAND & MADAGAS & $\begin{array}{l}\text { Comoros- } \\
\text { Mainland }\end{array}$ & $\begin{array}{l}\text { Madagacar- } \\
\text { Mainland }\end{array}$ & $\begin{array}{l}\text { Madagascar- } \\
\text { Comoros }\end{array}$ & $\begin{array}{l}\text { Comoros- } \\
\text { Mainland }\end{array}$ & $\begin{array}{l}\text { Madagacar- } \\
\text { Mainland }\end{array}$ & $\begin{array}{l}\text { Madagascar- } \\
\text { Comoros }\end{array}$ & \\
\hline Ctenochaetus_truncatus & Acanthuridae & IO & 0.86 & 0.79 & 0.3 & 0.64 & 1.24 & 1.32 & 79.28 & 10.15 & 20.29 & 48 \\
\hline Zebrasoma_velifer & Acanthuridae & IWP & 0.71 & 0.36 & 0.9 & 1.12 & 1.24 & 0.69 & 14.68 & 10.69 & 80.58 & 69 \\
\hline Pomacentrus_caeruleus & Pomacentridae & $\mathrm{IO}^{3}$ & 0.71 & 0.39 & 1 & 1.08 & 1.22 & 0.63 & 17.28 & 11.23 & 88.06 & $>180$ \\
\hline Pterocaesio_tile & Caesionidae & IWP & 0.86 & 0.79 & 0.3 & 0.64 & 1.24 & 1.32 & 79 & 11.77 & 20.84 & 49 \\
\hline Calotomus_carolinus & Scarinae & IP & 0.57 & 0.68 & 0.2 & 0.94 & 1.23 & 1.07 & 44.84 & 12.29 & 41.67 & 42 \\
\hline \multicolumn{13}{|c|}{ Additional Significant Species (Top 20) in Comoros-Mainland (Note C. argus and A. allardi, above, also Rank Here) } \\
\hline Heniochus_acuminatus & Chaeotodontidae & IWP & 0 & 0.79 & 0.6 & 1.88 & 0.88 & 1.2 & 1.45 & 60.56 & 27.75 & 12 \\
\hline Aprion_virescens & Lutjanidae & IWP & 0.71 & 0.21 & 0.5 & 1.27 & 0.99 & 0.99 & 6.43 & 46.28 & 47.41 & 40 \\
\hline Ostracion_meleagris & Ostraciidae & IP & 0.71 & 0.21 & 0.6 & 1.27 & 1.11 & 0.9 & 5.84 & 19.3 & 60.75 & 37 \\
\hline Chromis_lepidolepis & Pomacentridae & IWP & 0.29 & 0.75 & 0.5 & 1.23 & 0.99 & 0.99 & 8.14 & 32.72 & 55.92 & 45 \\
\hline Anampses_lineatus & $\begin{array}{l}\text { Labridae } \\
\text { S }\end{array}$ & RS-IO & 0.71 & 0.32 & 0.3 & 1.15 & 0.86 & 1.17 & 10.92 & 63.97 & 29.77 & 51 \\
\hline
\end{tabular}

${ }^{1}$ In IO reported only from East Africa, Seychelles, Madagascar, Mascarenes, Maldives, Chagos Archipelago, Andaman Sea and Java (Fricke et al. 2021). ${ }^{2}$ and Sri Lanka, RFM pers.obs. ${ }^{3}$ WIO to western Indonesia, RFM pers.obs.

\begin{tabular}{|c|c|c|c|c|c|}
\hline $\begin{array}{l}\text { significant in } \\
\text { Mada-Com and } \\
\text { Mada-Main }\end{array}$ & $\begin{array}{l}\text { only significant } \\
\text { in Mada-Com }\end{array}$ & $\begin{array}{l}\text { significant in } \\
\text { Mada-Com and } \\
\text { Com-main }\end{array}$ & $\begin{array}{l}\text { significant in } \\
\text { Mada-main } \\
\text { and Com-main }\end{array}$ & $\begin{array}{l}\text { only significant } \\
\text { in Mada-main }\end{array}$ & $\begin{array}{l}\text { only significant } \\
\text { in Com-main }\end{array}$ \\
\hline
\end{tabular}


The mean Dissimilarity/SD across all three pairwise comparisons provides a metric to rank species as most significant in all three SIMPER comparisons, with one representing the most highly ranked, Plectropomus punctatus (Table 3). The first 27 species (Variola louti is 27th) that ranked most highly out of the 356 observed species all appear in the MadagascarComoros comparisons, except for Cephalopholis argus and Chaetodon falcula, which explain differences between Madagascar and mainland countries, and Heniochus acuminatus, which explains differences between Comoros and mainland countries (Table 3).

Taking the top 20 species that most contributed to explaining differences (average cumulative dissimilarity of $12-14 \%$ ) in species assemblages between the three geographic zones, the following broad patterns can be seen (Table 3):

- the five most significant species in explaining differences between Comoros and Madagascar were very common in Madagascar but not sighted in Comoros: Plectropomus punctatus, Plectorhinchus gaterinus, Hipposcarus harid, Epibulis insidiator and Chaetodon vagabundus. All were moderately common in mainland countries except $C$. vagabundus, which was rare;

- $\quad$ other species explained differences between Comoros and Madagascar but did not appear in the top 20 species in other paired geographic zone comparisons, such as Pomacentrus baenschi and P. caeruleopunctatus, or were species common in Madagascar (in $80 \%$ of sites) but either rare or absent in mainland;

- $\quad$ high ranking species in Comoros were not sighted in Madagascar, e.g., Anampses twistii and Pygoplites diacanthus. Abudefduf vaigiensis, though less significant, was also common in Comoros and not sighted in Madagascar. Other species common in Comoros but rare/absent in Madagascar included Coris formosa, Mulloidichthys flavolineatus, and Parupeneus trifasciatus;

- other species that contributed to both Madagascar-Comoros and Madagascarmainland comparisons were common or relatively common across sites in Madagascar and mainland but were rare or absent in Comoros, such as Neoglyphidodon melas, Scarus ghobban, Cheilinus fasciatus and Cheilinus oxycephalus, and Chaetodon melannotus. With a similar distribution pattern though less significant was Lutjanus fulviflamma which was rare in Comoros. Scarus ghobban, (ranked 10th overall), was a key species distinguishing Comoros, where it was rare, from both Madagascar (8th rank) and mainland (20th rank, Table S3);

- $\quad$ species that were top ranking species contributing to the Comoros-mainland differences were not highly ranked in the other SIMPER results such as Aprion virescens, Ostracion meleagris and Heniochus acuminatus. The first two were more common in Comoros compared with mainland or Madagascar, whereas H. acuminatus was not sighted in Comoros. Chaetodon interruptus and Anampses lineatus were also common in Comoros and less common in mainland though were less significant in explaining differences;

- Amphiprion allardi and Cephalopholis argus were the only species significant in both island-mainland comparisons: A. allardi was only observed in mainland sites and C. argus was much more common in mainland sites.

In summary, the top 22 species that contributed most significantly to the differences in species occurrence and assemblage homogeneity between the three geographic zones (Table 3) were from 10 of the 19 families surveyed (where Scarinae are separated from Labridae): Labridae (six species), Chaetodontidae (4) Pomacentridae (3), Scarinae and Epinephelidae (two species of each), and one species in each of Acanthuridae, Lutjanidae, Haemulidae, Pomacanthidae, and Ostraciidae. Notably, very few larger bodied fishery species ranked highly in the dissimilarity rankings except Pletropomus punctatus and Plectorhinchus gaterinus. Five of the ten families ranked in the present study correspond to those most recommended as good indicators of reef fish diversity in other studies (Table 1). Notably absent from most of these other studies' recommendations are the Epinephelidae, Haemulidae and Ostraciidae. 


\section{Discussion}

\subsection{Biogeographic Patterns in Species Diversity}

The designation of the WIO as one biogeographic marine Province $[3,15,16]$ is supported by the species richness of coral reef fishes which was similar across the central WIO region surveyed, at $\sim 55 \%$ similarity. However, within the study area, significant differences in species presence were found which separated locations in Comoros from northeast Madagascar and these both differed from mainland eastern Africa. The highest species richness was found in locations in Tanzania and northern Mozambique, with the lowest species richness and most different species composition in Comoros. A lower species richness of corals from Comoros is also reported [21]. These findings, based on a sample of 356 species, provide evidence for three ecoregions within this central region of the WIO: eastern Africa (Tanzania, including Zanzibar, and northern Mozambique); Comoros; and north-eastern Madagascar. These ecoregions can represent conservation planning units for Marine Spatial Planning [45] or the Red Listing of Ecosystems [46].

Biogeography is a primary driver of patterns in species richness of reef fishes $[1,3,15,47]$. Factors such as the island effect, reef area, coast length and sea surface temperature are significant elements of this biogeography $[5,19,48,49]$. The three islands of the Union of Comoros are small, oceanic and recent volcanic islands [50] isolated from other large coral reef systems: $\sim 250 \mathrm{~km}$ from Mozambique and $\sim 450 \mathrm{~km}$ from Madagascar. The total coastline length and reef area in Comoros are $~ 70-90 \%$ smaller than mainland east Africa or Madagascar [51]. These biogeographic factors therefore likely explain the naturally lower species richness and different assemblages in Comoros. Less diversity of habitats may also be a contributing factor, but this could not be tested with the current sampling design. However, taxonomic diversity was highest in Comoros, driven by the Tetradontiformes. Likely reasons can only be speculative currently, but they may relate to the unique steep bathymetry of these volcanic islands.

Present day ocean currents [19] that drive the dispersal of pelagic larvae also help maintain biogeographic patterns. Further evidence for the ecoregions of Comoros, northern Madagascar and mainland east Africa comes from modelling pelagic larval duration (PLD) which separated eastern Africa from Comoros and Northern Madagascar using a short PLD of 10 days [52], generally shorter than most reef fishes. However, at 50 PLD this area became one homogeneous region, a finding verified by the genetics of two species common in the present study, Epinephelus merra and Lutjanus kasmira [53,54]. This finding lends further weight to the delineation of the WIO as one biogeographic province.

\subsection{Anthropogenic Influences}

Reefs of the WIO are intensely fished in many locations $[38,55,56]$, climate induced coral bleaching continues to degrade reefs [57] and both these impacts threaten some reef fish species [9] which could undermine studies examining patterns in species richness. However, fishing effects are largely seen in declines in biomass and fish size data [51,58,59], so with the species presence/absence data in the current study fishing effects will only manifest in zero values. Five species completely absent from Comoros and in the top 12 ranking species in the SIMPER analyses are species typically taken in WIO artisanal fisheries $[38,60]$. Two of these species, the grouper Plectropomus punctatus and the sweetlip Plectorhinchus gaterinus, are reported historically in Comoros [61] and at neighboring Mayotte the easternmost island in the Comoros Archipelago [62]. Both are widespread western Indian Ocean species and would be vulnerable to the coastal handline fisheries in Comoros [29] so their lack of sightings may indicate fishing effects. No confirmed sightings of Plectropomus punctatus in subsequent surveys in Moheli island in 2016 (B. Cowburn pers. comm.) and 2018 (M. Samoilys pers. obs.) further confirm this species is now very rare or locally extinct in these islands. Plectorhinchus gaterinus was also not sighted in surveys in Comoros in 2016 or 2018 and is reported as locally extinct in Reunion [32]. These two fishery species are therefore likely to have regional distribution patterns skewed by 
fishing. The other fishery species absent in Comoros are more easily explained through range restrictions or habitat requirements (see below).

\subsection{Species Level Differences}

Knowledge of the diversity and distribution of coral reef fishes is important for conservation planning under future climate change scenarios [63], yet species level data are still lacking over large spatial scales [1]. The present study fills this gap revealing regional species distribution patterns with assemblages in Comoros less speciose compared with the other three countries. Several species not sighted in Comoros included wide ranging IndoPacific species, those widely reported in the WIO, as well as WIO endemics. For example, widely distributed Indo-Pacific species were Epibulus insidiator, Chaetodon vagabundus, and Cheilinus fasciatus. However, they were sighted in Comoros in subsequent surveys in 2016 (B. Cowburn pers. comm.) and C. vagabundus was also sighted in 2018 (M. Samoilys pers. obs.), suggesting the zero sightings in the current study reflect rarity not absence. The WIO endemic anemone fish Amphiprion allardi ranked highly in the SIMPER analysis because it is restricted to the mainland east African coast and is replaced by A. latifasciatus in Comoros and Madagascar [64]. Therefore, earlier records of A. allardi from Mayotte, Glorieuses and the Mascarene Islands $[62,65,66]$ need updating. Other species not sighted in Comoros, Hipposcarus harid and Lutjanus fulviflamma, may be explained by restricted larval supply due to currents or habitat requirements. For example H. harid is reported from East Africa, western Madagascar [27], Mayotte island [62], and the French territories of Glorieuses and Geyser reef [67], but there are no records for Comoros in the Catalog of Fishes [42]. The reasons for this apparent disjunct distribution in the Comoros Archipelago require further study. Lutjanus fulviflamma is widely distributed in the WIO including Mayotte island [62]. Its absence in Comoros may be due to the juveniles' strong dependence on mangroves, which are uncommon in the islands of the Union of Comoros [51]. Only two species were common to Comoros but uncommon in the mainland countries and only moderately common in Madagascar: the snapper Aprion virescens and the boxfish Ostracion meleagris. This is possibly related to the predominantly steep narrow forereefs of these volcanic islands.

Principle species with restricted ranges that were driving regional differences include two Pomacentridae, Pomacentrus baenschi and Pomacentrus caeruleopuntatus, both reported as restricted to Madagascar and the Mascarene Plateau [65,68]. In the present study they were common in northeast Madagascar but sighted, though uncommon, in mainland (both species) and Comoros (P. caeruleopuntatus). These sightings require further investigation. In contrast, other species were ubiquitous in some locations and not in others, for example the parrotfish Scarus ghobban, with a wide Red Sea-Indo-West Pacific range [33], was sighted at every site in Madagascar, at just over half the mainland sites, but only $14 \%$ of the sites in Comoros. This pattern may reflect the small, isolated island effect (see above) and less diversity of habitats in Comoros.

Species missing from the northeast Madagascar sites are possibly explained by range restrictions due to ocean currents. Pygoplites diacanthus and Anampses twistii were not seen and Cephalopholis argus and Chaetodon falcula were rare, yet all are reported as widely distributed in the Indo-West Pacific [42] and in northwest Madagascar [27]. The South Equatorial Current (SEC) bifurcates east of Madagascar with the northern current flowing over the northern tip of Madagascar to continue to the Comoros and then the African continent, while the southern flow travels down the east coast of Madagascar to join the Algulhas current off South Africa [69]. The northeastern location of the present study may therefore represent Madagascan reefs where larval supply is weak because the SEC bifurcates further east, so self-recruitment is more prevalent [52]. Larval connectivity between the SEC, the west coast of Madagascar and the Comoros is likely to be strong due to the gyres in the north of the Mozambique Channel around the Comoros Archipelago [70]. Thus, species absent in northeast Madagascar are more likely explained by ocean currents 
restricting larval supply rather than "near threatened" as reported for Reunion where there are greater human pressures [65].

The ranges of the 46 species that contributed most to the patterns in diversity of species across this central WIO region were largely $(65 \%)$ highly wide ranging (IndoPacific, Red Sea-Indo-West Pacific) [42]. A further 30\% were wide ranging within the Indian Ocean, including the WIO, or Red Sea-Indian Ocean [15]. Only $4.3 \%$ of species were highly restricted, to the Mascarene Plateau [27]. Of conservation interest are the two nominally Mascarene species (Pomacentrus caeruleopuntatus and P. baenschi) and the six species restricted to the WIO Province, two of which (Plectropomus punctatus and Plectorhinchus gaterinus) are in severe decline [51]. Species that are endemic to the WIO [71], yet not seen during these surveys, provide a list of species of potential concern that may be disappearing due to loss of habitats through coral mortality. Additional surveys are recommended for these species, to be considered for Red Listing by the Species Survival Commission [72]. One example is Chaetodon blackburni, last assessed in 2010 as Least Concern [72], only know to occur in East and southern Africa, from Kenya to $33^{\circ} \mathrm{S}$, and Madagascar \& Mauritius [42], but not sighted once in this study. The functional roles of reef fish species, their contributions to ecosystem processes, are never equal, and it is postulated that in tropical systems each species contributes relatively little compared with temperate systems, due to high diversity in the tropics [73]. Further study on the ecological role of the 46 most significant species driving the regional patterns in the current study may reveal functional attributes important in ecosystem processes on coral reefs.

\subsection{Methods for Species Richness Surveys}

The presence/absence of species from 19 families surveyed by the timed UVC method in this study recorded $\sim 45 \%$ of the total putative number of reef species in the WIO [19] and was effective in detecting biogeographical patterns in assemblages and significant differences in species richness between locations. Further, total number of species per location were not different from predicted values, giving validity to the method and the total numbers of species observed. The biogeographical patterns span the central WIO across a latitudinal and longitudinal range of around eight and eleven degrees, respectively. Taxonomic distinctness also differed across this region suggesting it was valuable adding the Tetradontiformes order (Trigger, Box, Puffer and File fish families) to the check list, in addition to the more commonly monitored Perciform families. These values and diversity patterns provide a benchmark for species assemblages prior to the 2016 mass coral bleaching event, which was widespread in the WIO causing significant coral mortality [74].

Ten of the nineteen families contributed the top 22 species that showed significant differences in species occurrence and assemblage homogeneity between the three geographic zones. Of these, the highest number of species were in the Labridae, Chaetodontidae, Pomacentridae, Scarinae and Epinephelidae. These match four of the six families in the widely used Coral Fish Diversity Index (CFDI) [75]. The other five significant families in the present study were Acanthuridae, Lutjanidae, Pomacanthidae, Haemulidae and Ostraciidae. Notably, many of the families important in local fisheries, such as Lethrinidae, Siganidae, Carangidae, did not rank, even in the top 46 species significant in explaining location differences. For rapid assessment surveys that have to address multiple issues and also need to collect density and fish size estimates, a reduced list of eight families would suffice, such as: Chaetodontidae, Scarinae, Epinephelidae, Acanthuridae, Lutjanidae, Pomacanthidae, Haemulidae and Ostraciidae. These families were significant in the present study and are either speciose, good reef fish indicators, or have fishery importance [37,39,76-78]. Pomacentridae and Labridae are important highly speciose families, but being small and often difficult to identify are often not counted to species level in standard monitoring programs, such as GCRMN [79]. However, they added valuable diversity data here and are recommended if species identifications are possible. For detailed conservation planning, species level data are preferable. 


\section{Conclusions}

This study highlights that timed SCUBA surveys of reef fish species presence provide diversity metrics that are sensitive to change and can be used for conservation planning and to detect future impacts of conservation or reef degradation. For example, results indicate that conservation action in Comoros should prioritize protection of Plectropomus punctatus and Plectorhynchus gaterinus. The 22 most significant species that revealed patterns in diversity across the region came from the Scarinae, Chaetodontidae, Pomacentridae, Epinephelidae, Acanthuridae, Lutjanidae, Pomacanthidae, Haemulidae, and Ostraciidae suggesting these families should be considered for UVC surveys of reef fishes aiming to examine management, fishing effects and climate change on coral reefs. The current study provides a useful reference point for testing predictions of changes in reef fish species richness due to warming seas $[63,80]$.

The study documents the occurrence of 356 species of reef associated fishes for locations in four countries in the WIO that lie across the northern Mozambique Channel area where the highest coral diversity in the WIO is found [21]. Testing that this region is a diversity hotspot for reef fish species will require comparable data from more peripheral sites such as in Kenya, Seychelles, Mauritius and Reunion. Our findings provide evidence that the WIO biogeographic province contains distinguished ecoregions: Comoros Archipelago; northeastern Madagascar; and northern Mozambique and Tanzania, including Zanzibar. This separation of Comoros from eastern Africa differs from the ecoregions based on hermatypic corals [22,24]. These intraregional differences are relevant in coral reef threat assessments and informed the recent IUCN Red Listing of Ecosystems process for the WIO's coral reefs [81].

Supplementary Materials: The following are available online at https:/ /www.mdpi.com/article/ 10.3390/d14020102/s1, Figure S1: Total number of species per survey site $(n=45)$ in $>75$ min of observations, Figure S2: MDS plot showing four distinct groupings of the sites in terms of their species richness with Comoros and Madagascar separated and different from each other and the two mainland countries, Tanzania and Mozambique grouped together, with two outlier sites; Table S1: Final list of 45 survey sites used in analyses, showing countries, locations, reef geomorphology and reef type; Table S2: Full species inventory from all sites with taxonomic authority and taxonomic references. Table S3: Full SIMPER for all 356 species showing average Abundance, Dissimilarity, Cumulative contributions to Dissimilarity, and rankings.

Author Contributions: Conceptualization, M.S.; data curation, M.S. and L.A.-F.; formal analysis, L.A.-F.; writing—original draft, M.S.; writing—review \& editing, M.S., L.A.-F., P.C. and R.M. All authors have read and agreed to the published version of the manuscript.

Funding: This research was funded by the Western Indian Ocean Marine Science Association (WIOMSA), MASMA grant OR/2008/05; and Conservation International for the Madagascar surveys. M.S. was partly funded by a grant from the Perivoli Trust for a Senior Research Fellowship at the University of Oxford.

Institutional Review Board Statement: Not applicable. All data are underwater visual observations. Informed Consent Statement: Not applicable.

Data Availability Statement: Data from this study are provided in Tables S2 and S3 and will be made available on Dryad.

Acknowledgments: Grateful thanks to the following for comments and suggestions on the survey method: Howard Choat, Phil Heemstra, Ali Green, and Dave Bellwood. Gerry Allen's rapid reef fish diversity survey method for Conservation International, his comprehensive species lists for Madagascar, and help with identification of species from photographs were all invaluable. Thanks to Bemafaly Randriamanantsoa, Saleh Yahya, and Isabel da Silva as dive partners and for sharing their local knowledge of fish species. Thanks and appreciation to David Obura for stimulating discussions, fund raising, and help in several field trips. 
Conflicts of Interest: The authors declare no conflict of interest. The funders had no role in the design of the study; in the collection, analyses, or interpretation of data; in the writing of the manuscript, or in the decision to publish the results.

\section{References}

1. Mora, C. Large-scale patterns and processes in reef fish richness. In Ecology of Fishes on Coral Reefs; Mora, C., Ed.; Cambridge University Press: Cambridge, UK, 2015; pp. 88-96.

2. Hubert, N.; Dettai, A.; Pruvost, P.; Cruaud, C.; Kulbicki, M.; Myers, R.F.; Borsa, P. Geography and life history traits account for the accumulation of cryptic diversity among Indo-West Pacific coral reef fishes. Mar. Ecol. Prog. Ser. 2017, 583, 179-193. [CrossRef]

3. Bellwood, D.R.; Wainright, P.C. The history and biogeography of fishes on coral reefs. In Coral Reef Fishes; Sale, P., Ed.; Academic Press: Cambridge, MA, USA, 2002; pp. 5-32.

4. Stow, D. Vanished Ocean: How Tethys Reshaped the World; Oxford University Press: Oxford, UK, 2010.

5. Parravicini, V.; Kulbicki, M.; Bellwood, D.R.; Friedlander, A.M.; Arias-Gonzalez, J.E.; Chabanet, P.; Floeter, S.; Myers, R.; Vigliola, L.; D'Agata, S.; et al. Global patterns and predictors of tropical reef fish species richness. Ecography 2013, 36, $1254-1262$. [CrossRef]

6. Heron, S.F.; Maynard, J.A.; Van Hooidonk, R.; Eakin, C.M. Warming Trends and Bleaching Stress of the World's Coral Reefs 1985-2012. Sci. Rep. 2016, 6, 38402. [CrossRef] [PubMed]

7. Robinson, J.P.W.; Wilson, S.; Jennings, S.; Graham, N.A. Thermal stress induces persistently altered coral reef fish assemblages. Glob. Chang. Biol. 2019, 25, 2739-2750. [CrossRef] [PubMed]

8. Hughes, T.P.; Kerry, J.T.; Baird, A.H.; Connolly, S.R.; Dietzel, A.; Eakin, C.M.; Heron, S.; Hoey, A.S.; Hoogenboom, M.O.; Liu, G.; et al. Global warming transforms coral reef assemblages. Nature 2018, 556, 492-496. [CrossRef]

9. Graham, N.A.J.; Chabanet, P.; Evans, R.D.; Jennings, S.; Letourneur, Y.; Macneil, M.A.; McClanahan, T.R.; Öhman, M.C.; Polunin, N.V.C.; Wilson, S.K. Extinction vulnerability of coral reef fishes. Ecol. Lett. 2011, 14, 341-348. [CrossRef]

10. Graham, N.A.J.; McClanahan, T.R.; MacNeil, M.A.; Wilson, S.K.; Cinner, J.E.; Huchery, C.; Holmes, T.H. Human Disruption of Coral Reef Trophic Structure. Curr. Biol. 2017, 27, 231-236. [CrossRef]

11. Dana, J.D. On an isothermal oceanic chart illustrating the geographical distribution of marine animals. Am. J. Sci. 1853, 16, 153-167, 314-327.

12. Forbes, E. The Natural History of the European Seas; Goodwin-Austin, R., Ed.; Facsimile Publisher: London, UK, 1859.

13. Briggs, J.C. Marine Zoogeography; McGraw-Hill: New York, NY, USA, 1974.

14. Ekman, S. Zoogeography of the Sea; Sidgwick and Jackson: London, UK, 1953.

15. Briggs, J.C.; Bowen, B.W. A realignment of marine biogeographic provinces with particular reference to fish distributions. J. Biogeogr. 2012, 39, 12-30. [CrossRef]

16. Spalding, M.D.; Fox, H.E.; Allen, G.R.; Davidson, N.; Ferdaña, Z.A.; Finlayson, M.; Halpern, B.S.; Jorge, M.A.; Lombana, A.; Lourie, S.A.; et al. Marine ecoregions of the world: A bioregionalization of coastal and shelf areas. Bioscience 2007, 57, 573-583. [CrossRef]

17. IUCN. Managing Marine Protected Areas: A Toolkit for the Western Indian Ocean; IUCN Eastern Africa Regional Programme: Nairobi, Kenya, 2004.

18. McClanahan, T.R.; Sheppard, C.R.C.; Obura, D.O. (Eds.) Coral Reefs of the Indian Ocean; Oxford University Press: Oxford, UK, 2000.

19. Barber, P.H.; Meyer, C.P. Pluralism explains diversity in the Coral Triangle. In Ecology of Fishes on Coral Reefs; Mora, C., Ed.; Cambridge University Press: Cambridge, UK, 2015; pp. 258-263.

20. Carpenter, K.E.; Springer, V.G. The center of the center of marine shore fish biodiversity: The Philippine Islands. Environ. Biol. Fishes. 2005, 72, 467-480. [CrossRef]

21. Obura, D.O. An Indian Ocean centre of origin revisited: Palaeogene and Neogene influences defining a biogeographic realm. J. Biogeogr. 2015, 43, 229-242. [CrossRef]

22. Obura, D.O. The Diversity and Biogeography of Western Indian Ocean Reef-Building Corals. PLoS ONE 2012, 7, e45013. [CrossRef] [PubMed]

23. Obura, D.O.; Church, J.E.; Gabrié, C. Assessing Marine World Heritage from an Ecosystem Perspective: The Western Indian Ocean; UNESCO World Heritage Centre: Paris, France, 2012.

24. Veron, J.; Stafford-Smith, M.; DeVantier, L.; Turak, E. Overview of distribution patterns of zooxanthellate Scleractinia. Front. Mar. Sci. 2015, 2, 81. [CrossRef]

25. Burgess, N.D.; DAHales, J.D.A.; Underwood, E.; Dinerstein, E. (Eds.) Terrestrial Ecoregions of Africa and Madagascar: A Conservation Assessment; Island Press: Washington, DC, USA, 2004.

26. Mora, C.; Chittaro, P.M.; Sale, P.F.; Kritzer, J.P.; Ludsin, S.A. Patterns and processes in reef fish diversity. Nature 2003, $421,933-936$ [CrossRef]

27. Allen, G.R. Reef fishes of Northwestern Madagascar. In A Rapid Marine Biodiversity Assessment of the Coral Reefs of Northwest Madagascar; McKenna, S., Allen, G.R., Eds.; RAP Bullet; Conservation International: Washington, DC, USA, 2005 ; pp. 39-48. 
28. Samoilys, M.; Randriamanantsoa, B. Reef fishes of northeast Madagascar. In A Rapid Marine Biodiversity Assessment of the Coral Reefs of Northeast Madagascar; Obura, D., Di Carlo, G., Rabearisoa, A., Oliver, T., Eds.; Conservation International: Washington, DC, USA, 2011; pp. 29-39.

29. Cowburn, B.; Samoilys, M.A.; Obura, D. The current status of coral reefs and their vulnerability to climate change and multiple human stresses in the Comoros Archipelago, Western Indian Ocean. Mar. Pollut. Bull. 2018, 133, 956-969. [CrossRef]

30. Fricke, R.; Durville, P.; Bernardi, G.; Borsa, P.; Mou-Tham, G.; Chabanet, P. Checklist of the shore fishes of Europa Island, Mozambique Channel, southwestern Indian Ocean, including 302 new records. Stuttgarter Beiträge zur Naturkd A Neue Ser. 2013, 6, 247-276.

31. Chabanet, P.; Durville, P. Reef Fish Inventory of Juan De Nova's Natural Park (Western Indian Ocean). West Indian Ocean J. Mar. Sci. 2005, 4, 145-162. [CrossRef]

32. Fricke, R. Fishes of the Mascarene Islands (Mauritius, Réunion, Rodriguez). An Annotated Checklist, with Descriptions of New Species; Theses Zoo; Koeltz Scientific Books: Königstein, Germany, 1999.

33. Lieske, E.; Myers, R.F. Coral Reef Fishes, 2nd ed.; Princeton University Press: Princeton, NJ, USA, 2001.

34. Smith, M.; Heemstra, P.C. Smith's Sea Fishes; Springer-Verlag: Berlin, Germany, 1996.

35. Nelson, J.S. Fishes of the World, 4th ed.; John Wiley \& Sons Inc.: Hoboken, NJ, USA, 2006.

36. Kulbicki, M.; Vigliola, L.; Wantiez, L.; Floeter, S.; Hubert, N. The biogeography of Chaetodontidae, a model for reef fishes? In The Biology and Ecology of Butterfly-Fishes; Pratchett, M., Berumen, M., Kapoor, B., Eds.; CRC Press: Boca Raton, FL, USA, 2013; pp. 70-106.

37. Samoilys, M.; Roche, R.; Koldewey, H.; Turner, J. Patterns in reef fish assemblages: Insights from the Chagos Archipelago. PLoS ONE 2018, 13, e0191448. [CrossRef]

38. Samoilys, M.A.; Osuka, K.; Maina, G.W.; Obura, D.O. Artisanal fisheries on Kenya's coral reefs: Decadal trends reveal management needs. Fish Res. 2017, 186, 177-191. [CrossRef]

39. Bellwood, D.R. The Eocene fishes of Monte Bolca: The earliest coral reef fish assemblage. Coral Reefs. 1996, 15, 11-19. [CrossRef]

40. Choat, J.H.; Bellwood, D.R. Reef fishes: Their history and evolution. In The Ecology of Fishes on Coral Reefs; Sale, P.F., Ed.; Academic Press, Inc.: San Diego, CA, USA, 1991; pp. 39-61.

41. Munday, P.L.; Jones, G.P.; Pratchett, M.S.; Williams, A.J. Climate change and the future for coral reef fishes. Fish Fish 2008, 9 , 261-285. [CrossRef]

42. Fricke, R.; Eschmeyer, W.N.; van der Laan, R. Eschmeyer's Catalog of Fishes: Genera, Species, References; Fricke, R., Eschmeyer, W.N., van der Laan, R., Eds.; California Academy of Sciences: San Francisco, CA, USA, 2021.

43. Clarke, K.R.; Warwick, R.M. A further biodiversity index applicable to species lists: Variation in taxonomic distinctness. Mar. Ecol. Prog. Ser. 2001, 216, 265-278. [CrossRef]

44. Warwick, R.M.; Clarke, K.R. Taxonomic Distinctness and Environmental Assessment. J. Appl. Ecol. 1998, 35, 532-543. [CrossRef]

45. Zauca, J.; Gee, K. Maritime Spatial Planning: Past, Present, Future; Zauca, J., Gee, K., Eds.; Springer: Heidelberg, Germany, 2018.

46. Keith, D.; Rodríguez, J.; Rodríguez-Clark, K.; Nicholson, E.; Aapala, K.; Alonso, A.; Asmussen, M.; Bachman, S.; Basset, A.; Barrow, E.G.; et al. Scientific Foundations for an IUCN Red List of Ecosystems. PLoS ONE 2013, 8, e62111. [CrossRef] [PubMed]

47. D’Agata, S.; Mouillot, D.; Kulbicki, M.; Andréfouët, S.; Bellwood, D.R.; Cinner, J.E.; Cowman, P.; Kronen, M.; Pinca, S.; Vigliola, L. Human-mediated loss of phylogenetic and functional diversity in coral reef fishes. Curr. Biol. 2014, 24, 555-560. [CrossRef]

48. Barneche, D.R.; Rezende, E.L.; Parravicini, V.; Maire, E.; Edgar, G.J.; Stuart-Smith, R.D.; Arias-González, J.E.; Ferreira, C.E.L.; Friedlander, A.M.; Green, A.L.; et al. Body size, reef area and temperature predict global reef-fish species richness across spatial scales. Glob. Ecol. Biogeogr. 2019, 28, 315-327. [CrossRef]

49. Bellwood, D.R.; Hughes, T.P.; Connolly, S.R.; Tanner, J. Environmental and geometric constraints on Indo-Pacific coral reef biodiversity. Ecol. Lett. 2005, 8, 643-651. [CrossRef]

50. Audru, J.C.; Guennoc, P.; Thinon, I.; Abellard, O. Bathymay: La structure sous-marine de Mayotte révélée par l'imagerie multifaisceaux. Comptes. Rendus. Geosci. 2006, 338, 1240-1249. [CrossRef]

51. Samoilys, M.A.; Halford, A.; Osuka, K. Disentangling drivers of the abundance of coral reef fishes in the Western Indian Ocean. Ecol. Evol. 2019, 9, 4149-4167. [CrossRef]

52. Crochelet, E.; Roberts, J.; Lagabrielle, E.; Obura, D.; Petit, M.; Chabanet, P. A model-based assessment of reef larvae dispersal in the Western Indian Ocean reveals regional connectivity patterns-Potential implications for conservation policies. Reg. Stud. Mar. Sci. 2016, 7, 159-167. [CrossRef]

53. Muths, D.; Tessier, E.; Bourjea, J. Genetic structure of the reef grouper Epinephelus merra in the West Indian Ocean appears congruent with biogeographic and oceanographic boundaries. Mar. Ecol. 2015, 36, 447-461. [CrossRef]

54. Muths, D.; Gouws, G.; Mwale, M.; Tessier, E.; Bourjea, J. Genetic connectivity of the reef fish Lutjanus kasmira at the scale of the western Indian Ocean. Can. J. Fish. Aquat. Sci. 2012, 69, 842-853. [CrossRef]

55. Jacquet, J.; Fox, H.; Motta, H.; Ngusaru, A.; Zeller, D. Few data but many fish: Marine small-scale fisheries catches for Mozambique and Tanzania. Afr. J. Mar. Sci. 2017, 32, 2338. [CrossRef]

56. Rehren, J.; Samoilys, M.; Reuter, H.; Jiddawi, N. Integrating resource perception, ecological surveys, and fisheries statistics: A review of the fisheries in Zanzibar. Rev. Fish Sci. Aquac. 2020, 30, 1-18. [CrossRef]

57. Ateweberhan, M.; McClanahan, T.R.; Graham, N.A.J.; Sheppard, C.R.C. Episodic heterogeneous decline and recovery of coral cover in the Indian Ocean. Coral Reefs. 2011, 30, 739-752. [CrossRef] 
58. DeMartini, E.E.; Friedlander, A.M.; Sandin, S.A.; Sala, E. Differences in fish-assemblage structure between fished and unfished atolls in the northern Line Islands, central Pacific. Mar. Ecol. Prog. Ser. 2008, 365, 199-215. [CrossRef]

59. DeMartini, E.E.; Smith, J.E. Effects of fishing on the fishes and habitats of coral reefs. In Ecology of Fishes on Coral Reefs; Mora, C., Ed.; Cambridge University Press: Cambridge, UK, 2015; pp. 135-144.

60. Samoilys, M.A.; Osuka, K.; Mussa, J.; Rosendo, S.; Riddell, M.; Diade, M.; Mbugua, J.; Kawaka, J.; Hill, N.A.O.; Koldewey, H. An integrated assessment of coastal fisheries in Mozambique for conservation planning. Ocean Coast Manag. 2019, $182,104924$. [CrossRef]

61. Heemstra, P.C.; Randall, J.E. Groupers of the World (Family Serranidae, Subfamily Epinephelinae). An Annotated and Illsutrated Catalogue of the Grouper; Fisheries; FAO: Rome, Italy, 1993.

62. Wickel, J.; Jamon, A.; Pinault, M. Composition et Structure des Peuplements Ichtyologiques Marins de l'île de Mayotte (Sud-Ouest de L 'océan Indien); Société Française d'Ichtyologie: Paris, France, 2014; Volume 38, pp. 179-203.

63. Strona, G.; Lafferty, K.D.; Fattorini, S.; Beck, P.S.A.; Guilhaumon, F.; Arrigoni, R.; Montano, S.; Seveso, D.; Galli, P.; Planes, S.; et al. Global tropical reef fish richness could decline by around half if corals are lost. Proc. R Soc. B Biol. Sci. 2021, 288, 20210274. [CrossRef]

64. Fautin, D.G.; Allen, G.R. Field Guide to Anemonefishes and their Host Sea Anemones; West Australian Museum: Perth, Australia, 1992.

65. Fricke, R.; Mulochau, T.; Durville, P.; Chabanet, P.; Tessier, E.; Letourner, Y. Annotated checklist of the fish species (Pisces) of La Réunion, including a Red List of threatened and declining species. Stuttgarter Beiträge zur Naturkd A Neue Ser. 2009, 2, 1-168.

66. Durville, P.; Chabanet, P.; Quod, J.P. Visual Census of the Reef Fishes in the Natural Reserve of the Glorieuses Islands (Western Indian Ocean). West. Indian Ocean J. Mar. Sci. 2003, 2, 95-104. [CrossRef]

67. Chabanet, P.; Tessier, E.; Mulochau, T.; Durville, P.; Rene, F. Peuplement ichtyologique des Bancs des Geyser et Zelee (Ocean Indien Occidental). Cymbium 2002, 26, 11-26.

68. Bourjon, P.; Crochelet, E.; Fricke, R. First record of the large caerulean damselfish, Pomacentrus caeruleopunctatus (Actinopterygii: Perciformes: Pomacentridae), from reunion island, south-west indian ocean. Acta Ichthyol. Piscat. 2019, 49, 59-63. [CrossRef]

69. Schott, F.A.; Xie, S.P.; McCreary, J.P. Indian ocean circulation and climate variability. Rev. Geophys. 2009, 47, 1-46. [CrossRef]

70. Lutjeharms, J.R.E.; Bornman, T.G. The importance of the greater agulhas currentis increasingly being recognized. S. Afr. J. Sci. 2010, 106, 1-4. [CrossRef]

71. Kulbicki, M.; Parravicini, V.; Bellwood, D.R.; Arias-Gonzàlez, E.; Chabanet, P.; Floeter, S.R.; Friedlander, A.; McPherson, J.; Myers, R.E.; Vigliola, L.; et al. Global biogeography of reef fishes: A hierarchical quantitative delineation of regions. PLoS ONE 2013, 8, e81847. [CrossRef]

72. IUCN. The IUCN Red List of Threatened Species. Version 2021-2 [Internet]. 2021. Available online: https://www.iucnredlist.org (accessed on 19 November 2021).

73. Stuart-Smith, R.D.; Bates, A.E.; Lefcheck, J.S.; Duffy, J.E.; Baker, S.C.; Thomson, R.J.; Stuart-Smith, J.F.; Hill, N.A.; Kininmonth, S.J.; Airoldi, L.; et al. Integrating abundance and functional traits reveals new global hotspots of fish diversity. Nature. Nature 2013, 501, 539-542. [CrossRef]

74. Gudka, M.; Obura, D.; Mbugua, J.; Ahamada, S.; Kloiber, U.; Holter, T. Participatory reporting of the 2016 bleaching event in the Western Indian Ocean. Coral Reefs 2020, 39, 1-11. [CrossRef]

75. Allen, G.R.; Werner, T.B. Coral reef fish assessment in the coral triangle of southeastern Asia. Environ. Biol. Fishes 2002, 65, 209-214. [CrossRef]

76. Cole, A.C.; Pratchett, M.S.; Jones, J.P. Diversity and functional importance of coral-feeding fishes on tropical coral reefs. Fish Fish 2008, 9, 286-307. [CrossRef]

77. Samoilys, M.A.; Carlos, G. Determining methods of underwater visual census for estimating the abundance of coral reef fishes. Environ. Biol. Fishes 2000, 57, 289-304. [CrossRef]

78. Pratchett, M.S.; Munday, P.L.; Wilson, S.K.; Graham, N.A.J.; Cinner, J.E.; Bellwood, D.R.; Jones, G.P.; Polunin, N.V.; Mcclanahan, T.R. Effects of climate-induced coral bleaching on coral-reef fishes ecological and economic consequences. Oceanogr. Mar. Biol. 2008, 46, 251-296. [CrossRef]

79. Obura, D.O.; Gudka, M.; Abdou Rabi, F.; Bacha Gian, S.; Bigot, L.; Bijoux, J.; Freed, S.; Maharavo, J.; Mwaura, J.; Porter, S.N.; et al. Coral Reef Status Report for the Western Indian Ocean; Global Coral Reef Monitoring Network (GCRMN); International Coral Reef Initiative (ICRI); Indian Ocean Commission: Port Louis, Mauritius, 2017.

80. Pecl, G.T.; Araújo, M.B.; Bell, J.D.; Blanchard, J.; Bonebrake, T.C.; Chen, I.C.; Clark, T.D.; Colwell, R.K.; Danielsen, F.; Evengård, B.; et al. Biodiversity redistribution under climate change: Impacts on ecosystems and human well-being. Science 2017, 355, eaai9214. [CrossRef] [PubMed]

81. Obura, D.O.; Gudka, M.; Samoilys, M.; Osuka, K.; Mbugua, J.; Keith, D.A.; Porter, S.; Roche, R.; van Hooidonk, R.; Ahamada, S.; et al. Vulnerability to collapse of coral reef ecosystems in the Western Indian Ocean. Nat. Sustain. 2021. [CrossRef] 